\title{
Effects of Palm Vitamin E on Bone-Formation-Related Gene Expression in Nicotine-Treated Rats
}

\author{
Seham Salem Ahmed Abukhadir, ${ }^{1}$ Norazlina Mohamed, ${ }^{1}$ \\ Suzana Makpol, ${ }^{2}$ and Norliza Muhammad ${ }^{1}$
${ }^{1}$ Department of Pharmacology, Faculty of Medicine, Universiti Kebangsaan Malaysia, Jalan Raja Muda Abdul Aziz, 50300 Kuala Lumpur, Malaysia
${ }^{2}$ Department of Biochemistry, Faculty of Medicine, Universiti Kebangsaan Malaysia, Jalan Raja Muda Abdul Aziz, 50300 Kuala Lumpur, Malaysia \\ Correspondence should be addressed to Norazlina Mohamed, azlina@medic.ukm.my
}

Received 29 May 2012; Revised 16 July 2012; Accepted 18 July 2012

Academic Editor: Ahmad Nazrun Shuid

Copyright ( $) 2012$ Seham Salem Ahmed Abukhadir et al. This is an open access article distributed under the Creative Commons Attribution License, which permits unrestricted use, distribution, and reproduction in any medium, provided the original work is properly cited.

\begin{abstract}
The study determines the effects of palm vitamin $\mathrm{E}$ on the gene expression of bone-formation-related genes in nicotine-treated rats. Male rats were divided into three groups: normal saline olive oil (NSO), nicotine olive oil (NO), and nicotine palm vitamin E (NE). The treatment was carried out in 2 phases. During the first 2 months, the NSO group received normal saline while the NO and NE groups received nicotine $7 \mathrm{mg} / \mathrm{kg}$, 6 days a week, intraperitoneally. The following 2 months, normal saline and nicotine administration was stopped and was replaced with oral supplementation of olive oil for the NSO and NO groups and oral supplementation of palm vitamin E $(60 \mathrm{mg} / \mathrm{kg})$ for the NE group. Both femurs were harvested to determine the gene expression of bone morphogenetic protein-2 (BMP-2), Osterix (OSX), and Runt-related transcription factor 2 (RUNX2). Nicotine significantly downregulated the gene expression. This effect was reversed by palm vitamin E treatment. In conclusion, palm vitamin E may play a role in osteoblast differentiation and can be considered as an anabolic agent to treat nicotine-induced osteoporosis.
\end{abstract}

\section{Introduction}

Osteoporosis is a complex disorder with a large number of environmental risk factors that often interact in combinations. The bone deficit results from an imbalance in the normal relationship between bone formation and bone resorption, causing too little bone to be formed, too much removed, or both [1].

Most drugs available for the treatment of osteoporosis are inhibitors of bone resorption. They act either via reducing osteoclast number (such as bisphosphonates and estrogen) or osteoclast activity (cathepsin $\mathrm{K}$ inhibitors). However, in osteoporosis, bone loss may exceed the amount that can be restored by the inhibitors of resorption. Therefore, drugs that would act via promoting bone formation would be a tool for a highly desirable therapy [2].

Several studies have identified smoking as a risk factor for osteoporosis and bone fracture. Tobacco smoking inhibits the activity of osteoblasts and is an independent risk factor for osteoporosis. Smoking also results in increased breakdown of exogenous estrogens, lower body weight, and earlier menopause, all of which contribute to lower bone mineral density [3].

The study done by Gao et al. [4] has shown that smoke exposure can inhibit bone formation and increase bone resorption in female rat. Another study showed that nicotine has effects at the cellular level in human osteoblast cells [5]. It has also been shown to cause upregulation or downregulation of osteoblast regulatory genes and thus suppresses osteogenesis, promotes bone resorption, and delays osteoblast differentiation [6].

Vitamin E is an important fat-soluble vitamin with antioxidant properties. Of the two types of vitamin E, tocopherol is found in vegetable oils such as soy oil whereas tocotrienol is abundant in palm oil [7]. Previous studies have confirmed 
the beneficial effects of palm-oil-derived tocotrienol in several experimental osteoporosis; ovariectomized rats [8], steroid-induced rats [9], ferric-nitrilotriacetate-induced rats [10], and nicotine-induced rats $[11,12]$. Furthermore, recent study has shown that supplementation of palm vitamin $\mathrm{E}$, especially gamma isomer, can improve bone structural and biomechanical properties of normal male rats. Therefore, palm vitamin $\mathrm{E}$ has the potential to be used as an anabolic agent [13].

In this study, we focused on bone morphogenetic protein-2 (BMP-2), which is one of the growth factors known to induce bone and cartilage formation, RUNX2 and Osterix (OSX) which play a key role in osteoblast differentiation. This study aimed to provide a better understanding of the negative impact of smoking on bone health and offer evidence for the therapeutic potential of palm vitamin $\mathrm{E}$ in osteoporotic patients following cessation of smoking to improve bone health.

\section{Materials and Methods}

2.1. Animals and Treatment. Thirty-two young adult (3 months old) male Sprague-Dawley rats weighing 250$300 \mathrm{~g}$ were obtained from the Laboratory Animal Resource Unit, Faculty of Medicine, Universiti Kebangsaan Malaysia (UKM). Rats were randomly assigned to three groups with eight rats in each group; that is, normal saline olive oil (NSO), nicotine olive oil (NO), and nicotine palm vitamin E (NE). All rats received normal rat chow from Gold Coin (Port Klang, Malaysia). Rats were kept two per cage under 12-hour natural light-dark cycles and were given tap water. The treatment was carried out for 4 months and was divided into 2 phases. During the first 2-month duration, the NSO group received normal saline while the $\mathrm{NO}$ and NE groups received nicotine $7 \mathrm{mg} / \mathrm{kg}$, 6 days a week, intraperitoneally. The following 2 months, normal saline and nicotine were discontinued and oral supplementation of olive oil (NSO and NO groups) and palm vitamin E $60 \mathrm{mg} / \mathrm{kg}$ (NE group) was then given 6 days a week.

After 4 months of treatment, rats were sacrificed. Femur bones were extracted, attached soft tissues were removed, and the bones were rinsed with cold RNAase-free phosphatebuffered saline (Sigma, USA) before being flash-frozen with liquid nitrogen (Malaysian Oxygen, Malaysia). The bones were then stored at $-70^{\circ} \mathrm{C}$ until RNA extraction.

2.2. Diet, Nicotine, and Palm Vitamin E. The nicotine used was nicotine hydrogen tartrate salt, which was purchased from Sigma. Nicotine $(7 \mathrm{mg} / \mathrm{kg})$ was prepared by mixing $0.07 \mathrm{~g}$ of nicotine in $10 \mathrm{~mL}$ normal saline. A total of $0.1 \mathrm{~mL} / 100 \mathrm{~g}$ body weight of the preparation was given intraperitoneally 6 days a week according to the respective treatment duration. Palm vitamin E (3 g) was dissolved in $50 \mathrm{~mL}$ olive oil (Bertolli, Lucca, Italy) to obtain the $60 \mathrm{mg} / \mathrm{kg}$ rat weight dose. Palm vitamin E was obtained from Sime Darby Bioganic, Malaysia.
2.3. RNA Extraction and Quality Test. Purification of total RNA was done using the RNeasy Lipid Tissue Mini Kit according to the instructions of the manufacturer (Qiagen, Germany). RNA samples obtained were then stored at $-70^{\circ} \mathrm{C}$ until polymerase chain reaction (PCR) analysis was carried out. All RNA samples were quantified using the NanoDrop ND-1000 for quality control. The RNA concentration which was obtained was within acceptable range.

2.4. Primer Synthesis. Both forward and reverse primers for the genes of interest in this study were synthesized using primer 3 input software (version 0.4.0). The primer sequences and PCR product for our genes of interest are shown in Table 1.

2.5. Quantitative Real-Time PCR. Quantitative real-time PCR (qRT-PCR) was conducted using the iScript One-Step RT-PCR Kit with SYBR Green (Bio-Rad, USA). The reaction cocktail was assembled with all required components except sample template (total RNA), and equal aliquots were dispensed into each reaction tube. Target sample was then added to each reaction as the final step. Replicate samples were assembled as a master mix with a single addition of sample template. The reaction mixture and protocol were tabulated in Table 2. The PCR products were resolved on $2 \%$ agarose gel. Agarose gels were photographed for densitometry analysis using gel doc UV chamber with Quality One software (Bio-Rad, USA).

2.6. Relative Quantification Method. Relative quantification mathematical model was used to determine the relative quantification of a target gene in comparison to a reference gene. Relative quantification is based on internal reference genes to determine fold-differences in expression of the target gene. The relative amount of target gene is the difference between the cycle threshold $(\mathrm{Ct})$ of the gene and the $\mathrm{Ct}$ for the GAPDH. The crossing points, which are essential for calculation of relative expression ratios, were obtained, and relative expression ratios were calculated according to equation $\mathrm{REV}=2^{\text {(ct reference gene-ct target gene) }}$.

2.7. Statistical Analysis. Data was expressed as mean \pm standard error of the mean (SEM) and analyzed using "Statistical Package for Social Sciences" (SPSS version 15.0, Chicago, IL, USA). Parametric one-way analysis of variance (ANOVA) followed by post hoc (Tukey) tests was carried out for normally distributed data. Differences were considered significant at the levels $P<0.05$ for all statistical analysis.

The study was approved by the Universiti Kebangsaan Malaysia Animal Ethics Committee (UKMAEC) with the UKMAEC approval number: PP/FAR/2010/ NORAZLINA/20-January/285-January-2010-December2011.

\section{Results}

3.1. Confirmation of Primer Specificity. Specificity of RTPCR product was documented with high resolution gel 
TABLE 1: RT-PCR oligonucleotide primer.

\begin{tabular}{|c|c|c|c|}
\hline Gene description & Accession number & Primer sequence & PCR product size $(\mathrm{bp})$ \\
\hline \multirow{2}{*}{ GAPDH } & \multirow{2}{*}{ NM 017008} & F: 5'-GTG GAC CTC ATG GCC TAC AT-3' & \multirow{2}{*}{129} \\
\hline & & R: 5' -TGT GAG GGA GAT GCT CAG TG-3' & \\
\hline \multirow{2}{*}{ BMP-2 } & \multirow{2}{*}{ NM 017178} & F: $5^{\prime}$-TGA ACA CAG CTG GTC TCA GG-3' & \multirow{2}{*}{120} \\
\hline & & R: $5^{\prime}$-TTA AGA CGC TTC CGC TGT TT-3' & \\
\hline \multirow{2}{*}{ RUNX2 } & \multirow{2}{*}{ NM 053470} & F: 5'-GCC GGG AAT GAT GAG AAC TA-3' & \multirow{2}{*}{200} \\
\hline & & R: 5'-GGA CCG TCC ACT GTC ACT TT-3' & \\
\hline \multirow{2}{*}{ OsX } & \multirow{2}{*}{ NM 181374} & F: 5'-GCT GCC TAC TTA CCC GTC TG-3' & \multirow{2}{*}{137} \\
\hline & & R: $5^{\prime}$-GTT GCC CAC TAT TGC CAA CT-3' & \\
\hline
\end{tabular}

TABLE 2: SYBR Green real-time PCR reaction mixture and protocol.

Reaction mixture

\begin{tabular}{lc} 
Master mix & Volume per one reaction \\
\hline 2X SYBR Green RT-PCR reaction mix & $12.5 \mu \mathrm{L}$ \\
Forward primer $(10 \mu \mathrm{M})$ & $1 \mu \mathrm{L}$ \\
Reverse primer $(10 \mu \mathrm{M})$ & $1 \mu \mathrm{L}$ \\
Nuclease-free $\mathrm{H}_{2} \mathrm{O}$ & $9 \mu \mathrm{L}$ \\
RNA template $(1$ pg to 100 ng total & $1 \mu \mathrm{L}$ \\
RNA) & $0.5 \mu \mathrm{L}$ \\
iScript reverse transcriptase for & \\
one-step RT-PCR & $25 \mu \mathrm{L}$ \\
Final reactions volume &
\end{tabular}

Protocol

Process Duration/temperature

cDNA synthesis

$20 \mathrm{~min}$ at $50^{\circ} \mathrm{C}$

iScript reverse transcriptase inactivation

$4 \min$ at $95^{\circ} \mathrm{C}$

PCR cycling and detection (standard PCR cycle)

Denaturation

$10 \mathrm{sec}$ at $95^{\circ} \mathrm{C}$

Annealing/extension

$30 \mathrm{sec}$ at $61^{\circ} \mathrm{C}$ (data

collection step)

Repeated for (30 to 45 cycles)

$1 \mathrm{~min}$ at $95^{\circ} \mathrm{C}$

Melt curve analysis (optional)

$1 \mathrm{~min}$ at $55^{\circ} \mathrm{C}$

$10 \mathrm{sec}$ at $55^{\circ} \mathrm{C}(80$ cycles, increasing each by $0.5^{\circ} \mathrm{C}$ each cycle)

electrophoresis and resulted in a single product with the desired length (GAPDH, 129bp; BMP-2, 120 bp; OSX, 137 bp; RUNX, 200 bp) as shown in Figure 1.

3.2. BMP-2 Gene Expression. BMP-2 gene expression was decreased in the NO group compared to the NSO group $(P<0.05)$ (Figure 2$)$. However, BMP-2 expression was significantly increased in the NE group, when compared to the NO group $(P<0.05)$. The gene expression in the NE group was not significantly different from the NSO group.

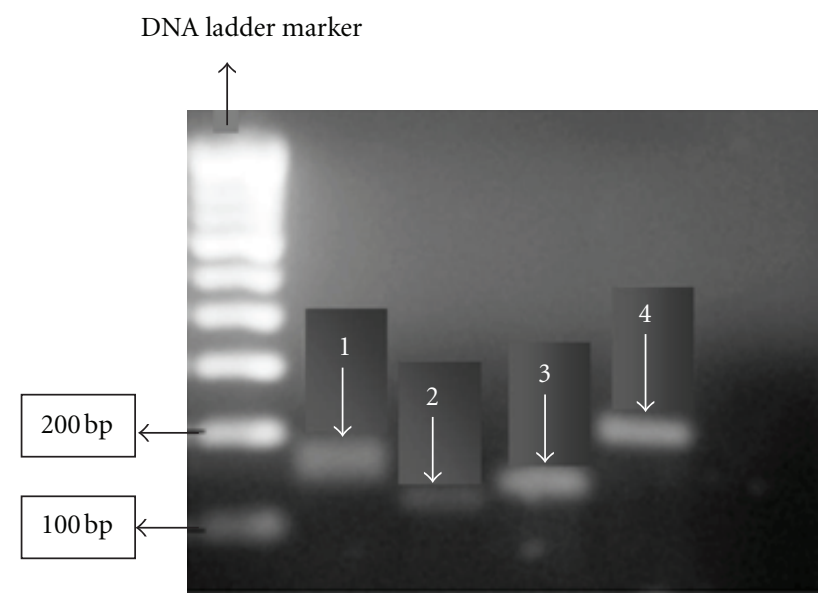

FIGURE 1: Agarose gel electrophoresis of PCR products. Lane1: OSX (129 bp). Lane 2: BMP-2 (120 bp). Lane 3: GAPDH (137 bp). Lane 4: RUNX2 (200 bp).

3.3. OSX Gene Expression. The expression level of OSX mRNA was markedly decreased in the NO group compared to the NSO group $(P<0.05)$. However, OSX expression level was significantly increased in NE group compared to the NO group $(P<0.05)$. The value for the NE group is still lower than the NSO group (Figure 3 ).

3.4. RUNX2 Gene Expression. The NO group had a lower RUNX2 gene expression as compared to the NSO $(P<$ 0.05 ) group (Figure 4). However, the expression increased significantly in the NE group, when compared to the NO group $(P<0.05)$. The RUNX2 gene expression of the NE group was not significantly different from the NSO group $(P$ $<0.05)$.

\section{Discussion}

Previous studies have shown that palm vitamin E $(60 \mathrm{mg} / \mathrm{kg})$ supplementation produced significant positive effects on bone metabolism in rats [14-17]. While a number of studies explored molecular responses associated with palm vitamin E treatment, there is paucity of studies on gene expression related to bone formation after a palm vitamin E treatment. 


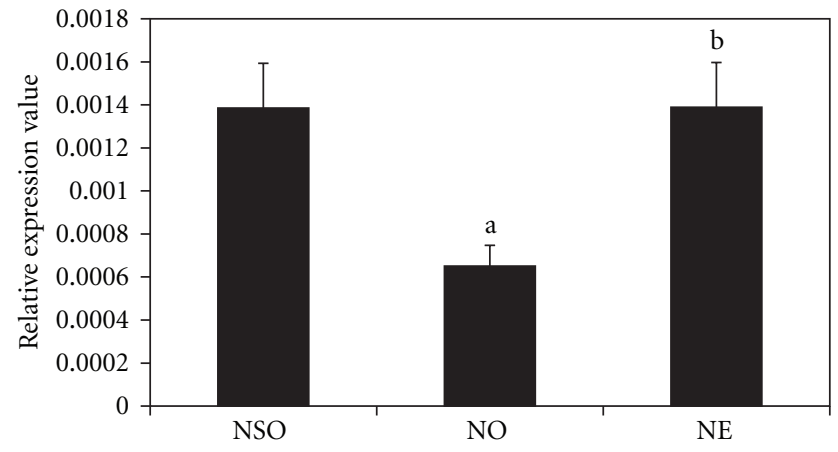

Figure 2: Effects of palm vitamin E on BMP-2 mRNA expression in nicotine-treated rats. Data is presented as mean \pm SEM. NSO: normal saline olive oil group. NO: nicotine olive oil group. NE: nicotine palm vitamin E group. ${ }^{a}$ Significantly different compared

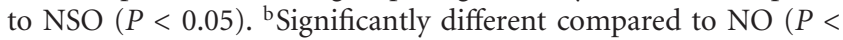
$0.05)$.

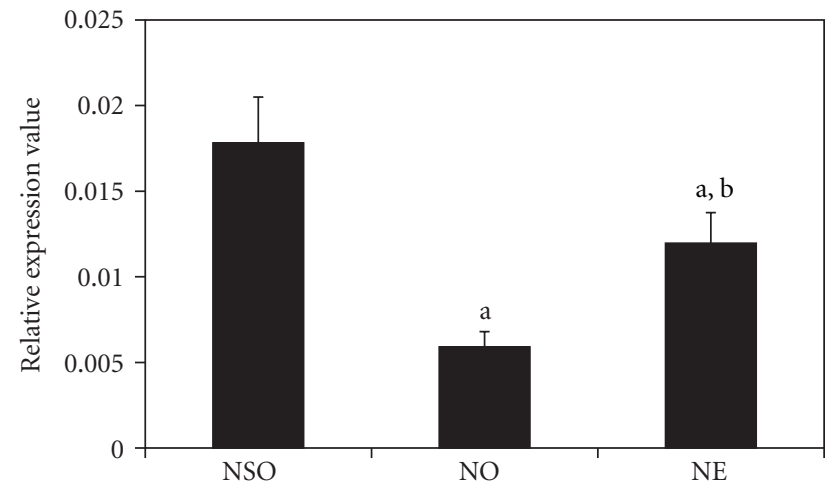

Figure 3: Effects of palm vitamin E on OSX mRNA expression in nicotine-treated rats. Data is presented as mean \pm SEM. NSO: normal saline olive oil group. NO: nicotine olive oil group. NE: nicotine palm vitamin E group. ${ }^{a}$ Significantly different compared to NSO $(P<0.05)$. ' Significantly different compared to NO $(P<$ $0.05)$.

In this study, we documented a significant decrease in BMP-2, OSX, and RUNX2 gene expressions in the nicotine olive oil group compared to the normal saline olive oil group. Our findings are in line with other researchers. A study done by Yanagita et al. [18] found that gene expressions of extracellular matrices and osteoblastic transcription factor (OSX) were reduced in nicotine-treated murine periodontal ligament cells. In another study, nicotine was shown to suppress osteoblast proliferation and inhibits the expression of some key osteogenic and angiogenic mediators in the in vitro experimental model [19]. In a more recent study, nicotine decreased RUNX2 in human alveolar bone marrowderived mesenchymal stem cells [20].

On the other hand, palm vitamin E treatment significantly increased the expression of the above genes after two months of nicotine exposure. These results suggested that palm vitamin $\mathrm{E}$ treatment may enhance osteoblast cell differentiation via upregulation of these bone-formationrelated genes. This mechanism could account for the increase

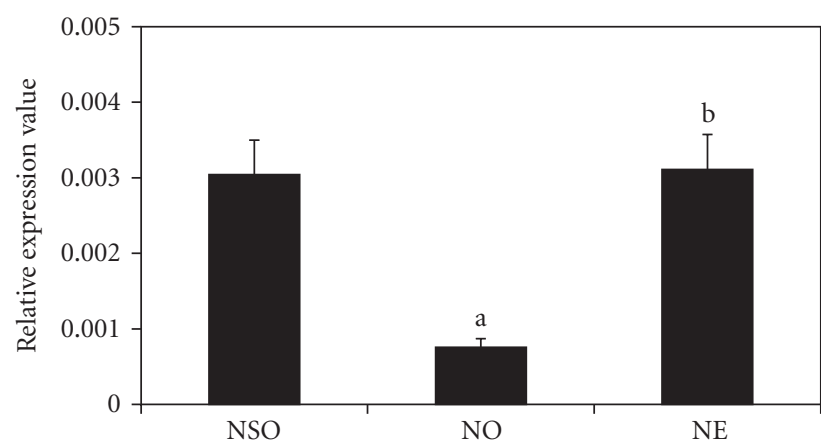

Figure 4: Effects of palm vitamin E on RUNX2 mRNA expression in nicotine-treated rats. Data is presented as mean \pm SEM. NSO: normal saline olive oil group. NO: nicotine olive oil group. NE: nicotine palm vitamin E group. ${ }^{a}$ Significantly different compared to NSO $(P<0.05)$. ' Significantly different compared to NO $(P<$ $0.05)$.

in bone formation activity observed after palm vitamin $\mathrm{E}$ treatment.

Nicotine may induce an oxidative stress condition. Oxidative stress has been shown to downregulate the expression of bone formation genes such as RUNX2 [21]. Therefore, palm vitamin $\mathrm{E}$ which possesses antioxidant properties may able to reverse the effects of nicotine on the gene expression.

Reports pertaining to vitamin $\mathrm{E}$ and bone-formationrelated genes are limited. However, other nutrients and vitamins have been shown to influence gene expression. One study showed that vitamin D strongly accelerates expression of genes involved in differentiation of human mesenchymal stem cells, moreover, identifies as a novel regulator of osteogenesis [22]. Xing et al. [23] found that ascorbic acid upregulated OSX expression via a novel mechanism involving nuclear translocation to activate genes critical for osteoblast cell differentiation. Other researchers have demonstrated that vitamin $\mathrm{D}$ exerts stimulatory effect on RUNX2 mRNA expression after 48 hours of treatment [24].

Future studies on the effects of palm vitamin $\mathrm{E}$ on other bone-formation-related genes such as the bone morphogenetic proteins (BMP-4, -5, -7), markers of bone formation such as alkaline phosphatase and osteocalcin, and growth factors such as fibroblast growth factor receptors $(1,2,3)$ may be important to support our results. In addition, boneresorption-related genes such as RANKL and OPG are also important for future studies to further validate these results.

\section{Conclusion}

In summary, palm vitamin $\mathrm{E}$ was able to upregulate the boneformation-related gene expressions in nicotine-treated rats. This effect may be useful in developing new anabolic agent in the treatment of metabolic bone disease such as osteoporosis.

\section{Conflict of Interests}

All authors have no conflict of interests to declare. 


\section{Acknowledgments}

The authors were grateful to Universiti Kebangsaan Malaysia for funding the research under Grant no. FF-095-2010. The authors would like to thank Ms. Azizah Osman and Mr. Arizi Aziz for their technical assistance.

\section{References}

[1] L. G. Raisz, "Pathogenesis of osteoporosis: concepts, conflicts, and prospects," Journal of Clinical Investigation, vol. 115, no. 12, pp. 3318-3325, 2005.

[2] B. L. Riggs and A. M. Parfitt, "Drugs used to treat osteoporosis: the critical need for a uniform nomenclature based on their action on bone remodeling," Journal of Bone and Mineral Research, vol. 20, no. 2, pp. 177-184, 2005.

[3] P. K. Wong, J. J. Christie, and J. D. Wark, "The effects of smoking on bone health," Clinical Science, vol. 113, pp. 233241, 2007.

[4] S. G. Gao, K. H. Li, M. Xu et al., "Bone turnover in passive smoking female rat: relationships to change in bone mineral density," BMC Musculoskeletal Disorders, vol. 12, article 131, 2011.

[5] L. M. Walker, M. R. Preston, J. L. Magnay, P. B. M. Thomas, and A. J. El Haj, "Nicotinic regulation of c-fos and osteopontin expression in human-derived osteoblast-like cells and human trabecular bone organ culture," Bone, vol. 28 , no. 6, pp. 603 608,2001 .

[6] D. E. Rothem, L. Rothem, M. Soudry, A. Dahan, and R. Eliakim, "Nicotine modulates bone metabolism-associated gene expression in osteoblast cells," Journal of Bone and Mineral Metabolism, vol. 27, no. 5, pp. 555-561, 2009.

[7] A. Azzi and A. Stocker, "Vitamin E: non-antioxidant roles," Progress in Lipid Research, vol. 39, no. 3, pp. 231-255, 2000.

[8] M. Norazlina, S. Ima-Nirwana, M. T. Gapor, and B. A. K. Khalid, "Palm vitamin E is comparable to $\alpha$-tocopherol in maintaining bone mineral density in ovariectomised female rats," Experimental and Clinical Endocrinology and Diabetes, vol. 108, no. 4, pp. 305-310, 2000.

[9] S. Ima-Nirwana and H. Fakhrurazi, "Palm vitamin E protects bone against dexamethasone induced osteoporosis in male rats," Medical Journal of Malaysia, vol. 57, pp. 136-144, 2002.

[10] N. S. Ahmad, B. A. K. Khalid, D. A. Luke, and S. I. Nirwana, "Tocotrienol offers better protection than tocopherol from free radical-induced damage of rat bone," Clinical and Experimental Pharmacology and Physiology, vol. 32, no. 9, pp. 761-770, 2005.

[11] M. Norazlina, P. L. Lee, H. I. Lukman, A. S. Nazrun, and S. Ima-Nirwana, "Effects of vitamin E supplementation on bone metabolism in nicotine-treated rats," Singapore Medical Journal, vol. 48, no. 3, pp. 195-199, 2007.

[12] H. Hermizi, O. Faizah, S. Ima-Nirwana, S. Ahmad Nazrun, and M. Norazlina, "Beneficial effects of tocotrienol and tocopherol on bone histomorphometric parameters in SpragueDawley male rats after nicotine cessation," Calcified Tissue International, vol. 84, no. 1, pp. 65-74, 2009.

[13] N. S. Ahmad, M. Zulfadli, M. Norazlina et al., "Vitamin E exhibits bone anabolic actions in normal male rats," Journal of Bone and Mineral Metabolism, vol. 28, no. 2, pp. 149-156, 2010.

[14] S. Ima-Nirwana, A. Kiftiah, T. Sariza, M. T. A. Gapor, and B. A. K. Khalid, "Palm vitamin E improves bone metabolism and survival rate in thyrotoxic rats," General Pharmacology, vol. 32, no. 5, pp. 621-626, 1999.

[15] N. S. Ahmad, B. A. K. Khalid, and S. Ima-Nirwana, "Effects of vitamin $\mathrm{E}$ on interleukin-1 in ferric nitrilotriacetate treated rats," Malaysian Journal of Biochemistry and Molecular Biology, vol. 9, pp. 43-47, 2004.

[16] N. S. Ahmad, B. A. K. Khalid, D. A. Luke, and S. I. Nirwana, "Tocotrienol offers better protection than tocopherol from free radical-induced damage of rat bone," Clinical and Experimental Pharmacology and Physiology, vol. 32, no. 9, pp. 761-770, 2005.

[17] M. Norazlina, F. W. Ng, and S. Ima-Nirwana, "Gammatocotrienol is required for normal vitamin D metabolism in female rats," Indian Journal of Pharmacology, vol. 37, no. 5, pp. 309-314, 2005.

[18] M. Yanagita, Y. Kojima, T. Kawahara et al., "Suppressive effects of nicotine on the cytodifferentiation of murine periodontal ligament cells," Oral Diseases, vol. 16, no. 8, pp. 812-817, 2010.

[19] L. Ma, R. A. Zwahlen, L. W. Zheng, and M. H. Sham, "Influence of nicotine on the biological activity of rabbit osteoblasts," Clinical Oral Implants Research, vol. 22, no. 3, pp. 338-342, 2011.

[20] B. S. Kim, S. J. Kim, H. J. Kim et al., "Effects of nicotine on proliferation and osteoblast differentiation in human alveolar bone marrow-derived mesenchymal stem cells," Life Sciences, vol. 90, pp. 109-115, 2012.

[21] C. Mazière, V. Savitsky, A. Galmiche, C. Gomila, Z. Massy, and J. C. Mazière, "Oxidized low density lipoprotein inhibits phosphate signaling and phosphate-induced mineralization in osteoblasts. Involvement of oxidative stress," Biochimica et Biophysica Acta, vol. 1802, no. 11, pp. 1013-1019, 2010.

[22] E. Piek, L. S. Sleumer, E. P. van Someren et al., "Osteotranscriptomics of human mesenchymal stem cells: accelerated gene expression and osteoblast differentiation induced by vitamin D reveals c-MYC as an enhancer of BMP2-induced osteogenesis," Bone, vol. 46, no. 3, pp. 613-627, 2010.

[23] W. Xing, A. Singgih, A. Kapoor, C. M. Alarcon, D. J. Baylink, and S. Mohan, "Nuclear factor-E2-related factor-1 mediates ascorbic acid induction of osterix expression via interaction with antioxidant-responsive element in bone cells," Journal of Biological Chemistry, vol. 282, no. 30, pp. 22052-22061, 2007.

[24] V. Viereck, H. Siggelkow, S. Tauber, D. Raddatz, N. Schutze, and M. Hüfner, "Differential regulation of Cbfa1/Runx2 and osteocalcin gene expression by vitamin-D3, dexamethasone, and local growth factors in primary human osteoblasts," Journal of Cellular Biochemistry, vol. 86, no. 2, pp. 348-356, 2002. 


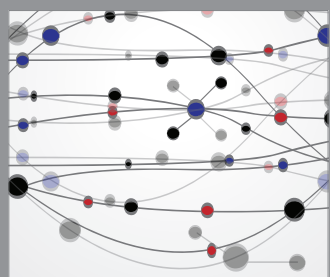

The Scientific World Journal
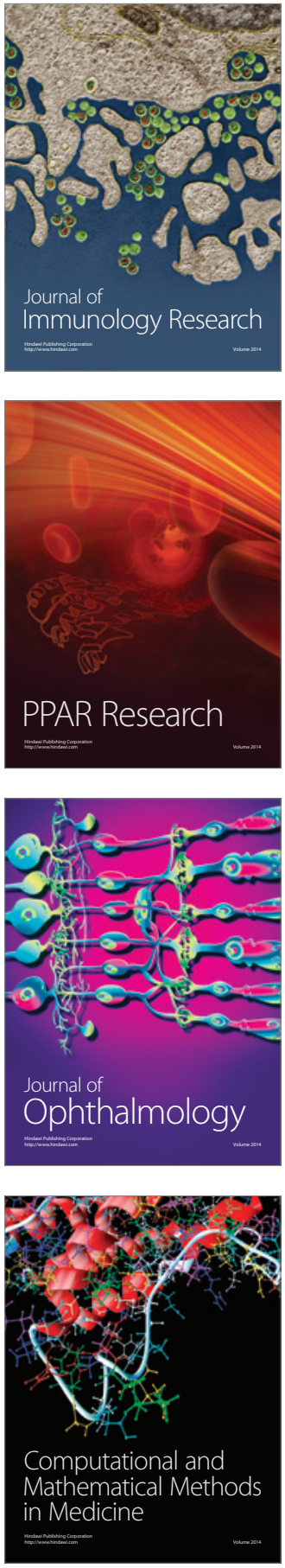

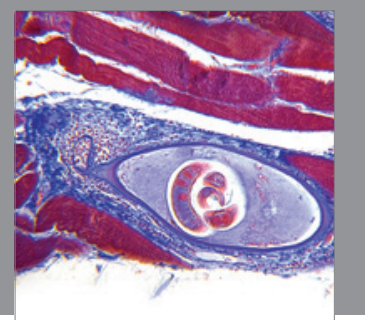

Gastroenterology

Research and Practice
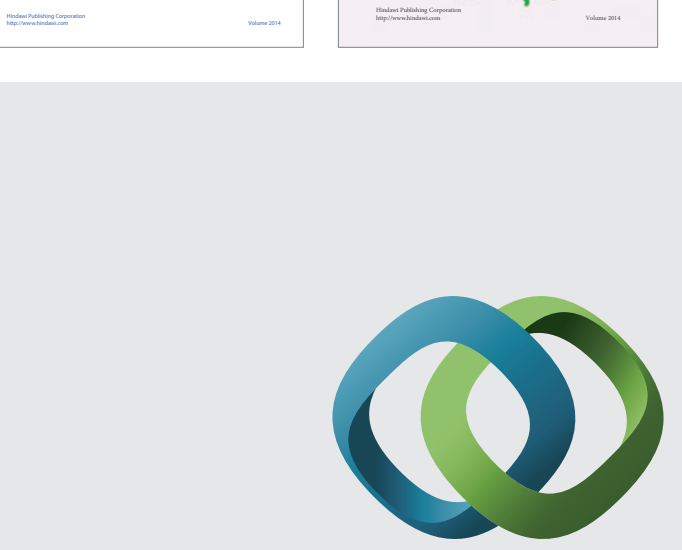

\section{Hindawi}

Submit your manuscripts at

http://www.hindawi.com
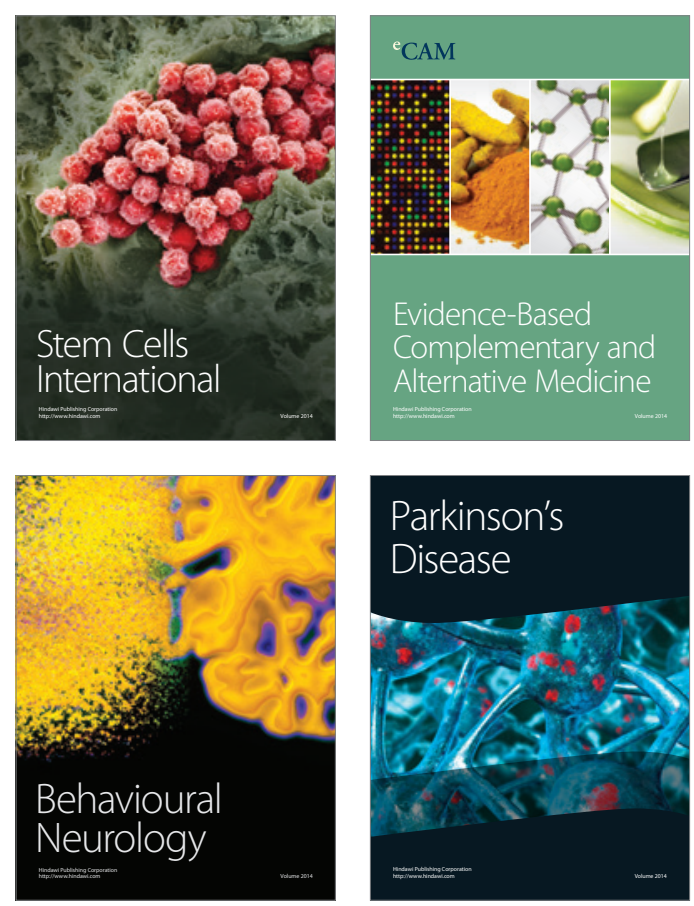

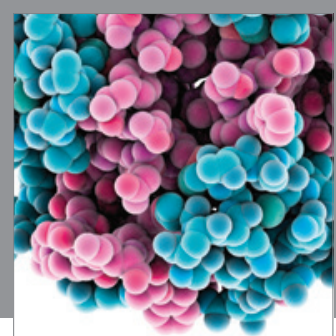

Journal of
Diabetes Research

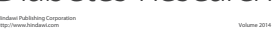

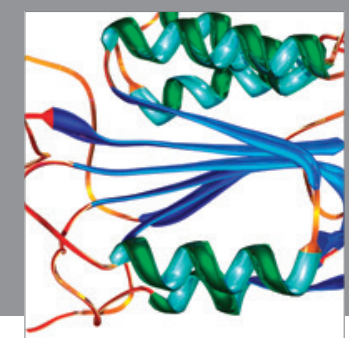

Disease Markers
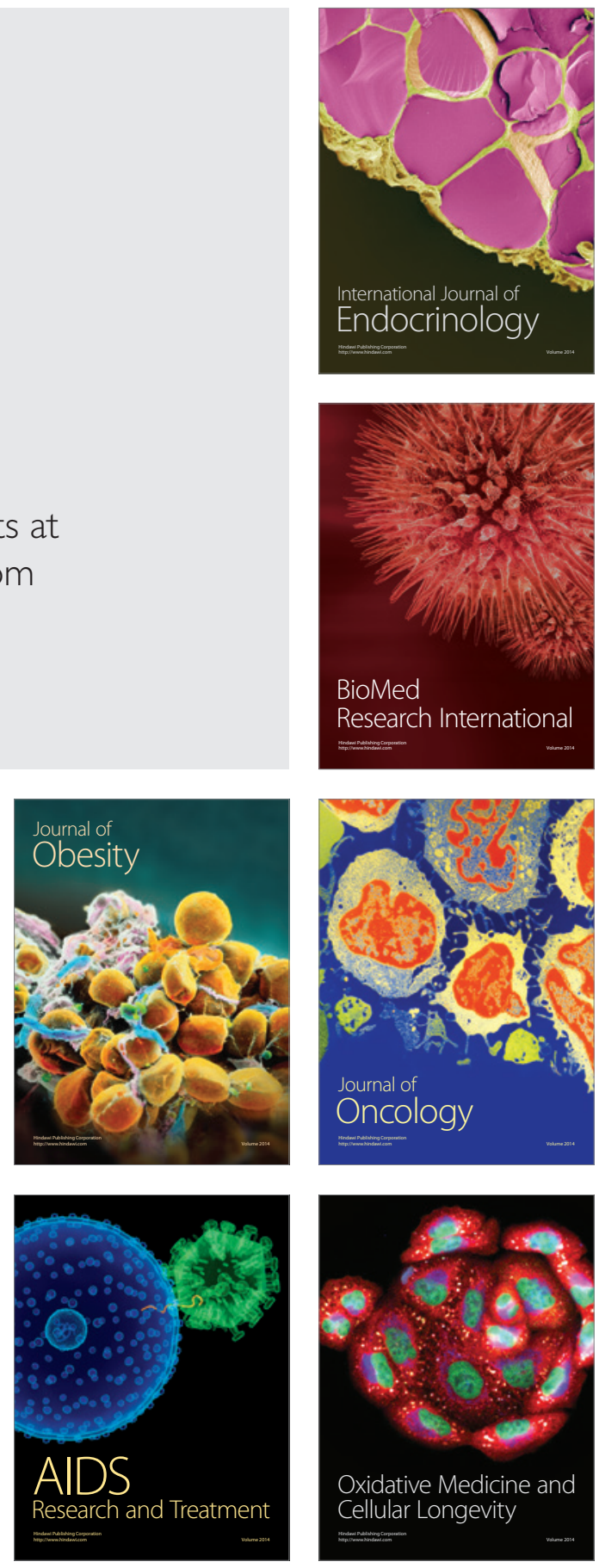